\title{
Strategies used in the translation of fixed expressions in magazines: A comparison of selected texts with Afrikaans as source language and South African English as target language
}

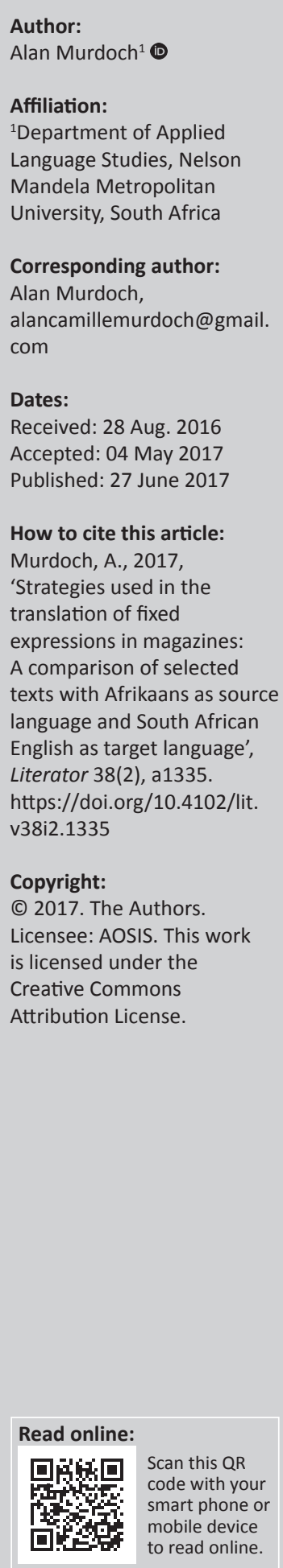

This article will look at the translation of idioms and other types of fixed expressions from Afrikaans (the source language) into South African English (the target language), from selected texts in Huisgenoot and You magazines from a study conducted over the 10-week period from 18 July 2013 to 19 September 2013. The article will start by looking at the difficulties in defining idioms and other types of fixed expressions and will draw on the work of Rosamund Moon for this. It then uses the strategies on the translation of idioms (and other types of fixed expressions) in Mona Baker's In Other Words to categorise a set of 70 such expressions according to the strategy used to translate them and concludes by looking at whether equivalence is obtained.

Strategieë gebruik in die vertaling van vaste uitdrukkings in tydskrifte: 'n Vergelyking van geselekteerde tekste met Afrikaans as brontaal en Suid-Afrikanse Engels as doeltaal. Hierdie artikel sal kyk na die vertaling van idiome en ander vorme van vaste uitdrukkings uit Afrikaans (die brontaal) na Suid-Afrikanse Engels (die doeltaal), van geselekteerde tekste in Huisgenoot en You. Dit was deel van 'n studie wat oor 'n tydperk van tien weke (van 18 Julie 2013 tot 19 September 2013) uitgevoer is. Die artikel begin deur te kyk na die probleme wat betref die definisie van idiome en ander vorme van vaste uitdrukkings, en put hier veral uit die werk van Rosamund Moon. Dit gebruik dan die strategieë vir die vertaling van idiome (en ander vorme van vaste uitdrukkings) in Mona Baker se In Other Words om 'n stel van 70 sulke uitdrukkings te kategoriseer en sluit af deur te kyk of ekwivalensie verkry word.

\section{Introduction}

In the multicultural and multilingual post-Apartheid South Africa, with its 11 official languages, all of which have a constitutional requirement to be protected and promoted, publishers of popular magazines would be remiss to ignore markets and readers based on their language preference. Indeed, according to Media24, the company that publishes both Huisgenoot and You (Media24 2016a, 2016b), 'Huisgenoot is the magazine with the highest circulation in South Africa over two million people read the magazine weekly'. The website also says of Huisgenoot's sister publication, You, that 'With over [two] million readers a week YOU is the biggest-selling English magazine in the country' (Media24 2016a, 2016b).

Huisgenoot and You, both published on a weekly basis, are sister publications as they feature almost entirely the same content in each issue, in Afrikaans and South African English (henceforth English), respectively. They are thus an ideal medium for looking at translation between Afrikaans and English, especially with respect to the use of fixed expressions and idioms as a subdivision of fixed expressions. Both Huisgenoot and You are marketed to families, with the result that many South Africans, from all walks of life come into contact with the magazines on a regular basis and also read them.

\section{According to Charteris-Black (2003):}

It is through figurative modes of thought that a culture signifies its unique view of the world; it is this uniqueness which presents the greatest problem for the translator of idioms. (p. 125)

This suggests that idioms present somewhat of a double-edged sword to the translator: firstly, they form an intricate part of a particular language and specifically a way of representing 
its peoples' culture, and secondly, they often present the translator with the problem of how to translate them into a target language and culture which may be partially, or even wholly unfamiliar with the culture of the source language and thus not necessarily have an appropriate idiom to replace it with. According to Baker (2011):

A fixed expression [including idioms] evokes in the mind of the reader or hearer a range of associations connected with the typical contexts in which the expression is used. It is precisely this feature which lies behind the widespread use of fixed and semi-fixed expressions in any language. (p. 68)

The purpose of this article is then to investigate the translation of fixed expressions (including idioms) from Afrikaans (the source language) into English (the target language) from selected texts in Huisgenoot and You magazines during the 10-week period from 18 July 2013 to 19 September 2013 (Media24 2013a-t). As already mentioned, both magazines have a large number of readers and both contain essentially the same content. The publications are thus an ideal source of translation in action, in that they contain translations of everyday language and (fixed) expressions used by South Africans when speaking Afrikaans and English. This article will thus look at how these fixed expressions were translated from Afrikaans to English and whether equivalence was obtained. Equivalence is a seminal concept in translation studies and Baker and Saldanha (2009:96) define 'equivalence as a relationship between two texts: a source text (ST) and a target text (TT)'. Equivalence can be sought, or said to exist, at any of a number of levels in the translation. Hartmann et al. cited in Bell (1991) say that 'Translation is the replacement of a representation of a text in one language by a representation of an equivalent text in a second language' and they go on to say that:

Texts in different languages can be equivalent in different degrees (fully or partially equivalent), in respect of different levels of presentation (equivalent in respect of context, of semantics, of grammar, of lexis, etc.) and at different ranks (word-for-word, phrase-for-phrase, sentence-for-sentence). (p. 6)

The study will use the strategies detailed by Mona Baker in In Other Words (2011) on the translation of idioms and fixed expressions to determine whether the strategies can be used in the translation of idioms or other types of fixed expressions with Afrikaans as the source language and English as the target language, or in the absence of a translation equivalent between the two texts, whether they could have been used to obtain one. The article will also investigate whether or not the strategies can offer better translation equivalents (TEs) than the ones used in the TTs.

\section{Defining fixed expressions and idioms}

Despite the common use and existence of terms such as 'fixed expression' and 'idiom', it is not so straightforward to define these two concepts. Moon (1998:2) says that 'Fixed expression is a very general but convenient term', under which she includes, inter alia, the likes of frozen collocations, grammatically ill-formed collocations, proverbs, sayings, similes and idioms. She goes on to say that 'Fixed expression, like idiom, is unsatisfactory as a term, as it will be seen that many fixed expressions of these types are not actually fixed', but concedes that she uses it 'for simplicity's sake'.

According to the Collins English Dictionary (Black et al. 2009:820), an idiom is defined as 'a group of words whose meaning cannot be predicted from the meanings of the constituent words'. It also defines an idiom as 'linguistic usage that is grammatical and natural to native speakers of a language'. Similarly, The Cambridge Dictionary of Linguistics (Brown \& Miller 2013:173) says that 'Many fixed expressions, both phrases and clauses, are idioms, that is fixed expressions whose meaning cannot be guessed from their individual words'. This is quite an important aspect when it comes to translation, as a native speaker of English is likely to recognise an idiom, not least of all because it might not make sense on a literal level within the context in which it is presented. On the other hand, a second language speaker, or someone learning English, may not pick up on the fact that an idiom is being used and then translate it directly into their target language and in so doing lose the meaning of the idiom, or even distort the meaning of the translation as a whole. As Baker (2011) says:

A person's competence in actively using the idioms and fixed expressions of a foreign language hardly ever matches that of a native speaker. The majority of translators working in a foreign language cannot hope to achieve the same sensitivity that native speakers seem to have for judging when and how an idiom can be manipulated. (p. 68)

A seemingly small but ultimately crucial part of the definition of an idiom and indeed any fixed expression comes from the definition of an idiom on the Oxford Dictionaries website (Oxford University Press 2016), which includes the phrase 'a group of words established by usage'. While this is true of all languages, that is, it develops and changes through usage, it is particularly true of fixed expressions and idioms which have only attained their status as such through continued usage in everyday language by speakers of the language in question. Even though idioms are generally thought of as being a group of words, as per the above definition, Svensén (2009:188) does point out that 'the concept [of an idiom] is sometimes more widely defined, for instance to include compounds where the meaning cannot be inferred from the meanings of the elements, e.g. headlong'.

Taking as an example the English idiom which says that 'a bird in the hand is worth two in the bush', someone not familiar with this idiom is likely to be very confused by it. If pressed to suggest a meaning for it, they would most probably suggest that it has something to do with birds and hunting - neither of which strictly pertain to the meaning of the idiom as used. According to the Phrase Finder website (Martin 2016), the origin of the expression does pertain to birds, particularly falcons, but the meaning of the expression has evolved such that it no longer pertains specifically, or even at all, to birds or falconry. This clearly shows what is 
meant by the words being 'established by usage' in the definition from the Oxford Dictionaries website (Oxford University Press 2016); that is, through the use of the expression, it takes on a certain meaning. This change in meaning over time is described by Svensén (2009) when he says that:

Originally, all idioms had a more or less literal meaning, which then became more and more figurative, finally ending up as expressions where the original meanings of the individual components had faded. (p. 190)

The idiom actually means that any advantage is better than none, so it is clear that its meaning has nothing to do with birds, whether in your hand or somewhere in the bush as the words suggest.

Another example of an idiom which uses birds is 'to kill two birds with one stone'. Here a direct analysis of the words would suggest the throwing of a stone and killing two birds with it, but once again the meaning of the idiom, which is to accomplish or complete two things through a single action, has nothing to do with killing birds with a stone.

Moon (1998:3) points out that 'Idiom is an ambiguous term, used in conflicting ways', and this is in reference to the fact that the term idiom can also be used in music and art, but this article only deals with it in terms of language use. Accordingly, she goes on to say that 'narrower uses restrict idiom to a particular kind of unit: one that is fixed and semantically opaque', and 'In broader uses, idiom is a general term for many kinds of multi-word items, whether semantically opaque or not' (1998:4). According to Bolinger in Moon (1998):

There is no clear boundary between an idiom and a collocation or between a collocation and a freely generated phrase - only a continuum with greater density at one end and greater diffusion at the other. (p. 6)

\section{Along these lines, Baker (2011) says that:}

Idioms and fixed expressions are at the extreme end of the scale from collocations in one or both of these areas: flexibility of patterning and transparency of meaning. They are frozen patterns of language which allow little or no variation in form and, in the case of idioms, often carry meanings which cannot be deduced from their individual components. (p. 67)

Unlike idioms, fixed expressions generally have more transparent meanings, that is, their meaning can be deduced from their constituent words. Salutations such as 'happy birthday' and 'merry Christmas' and greetings such as 'yours sincerely' or 'yours faithfully' are examples of fixed expressions that commonly occur in and are associated with specific occurrences, such as social events and written correspondence respectively and which are to be literally interpreted. Baker (2011:67-68), however points out that in spite of its transparency, the meaning of a fixed expression [...] is somewhat more than the sum meanings of its words' and that 'the expression has to be taken as one unit to establish meaning'. She goes on to say that:
A fixed expression evokes in the mind of the reader or hearer a range of associations connected with the typical contexts in which the expression is used. It is precisely this feature which lies behind the widespread use of fixed [...] expressions in any language. They encapsulate stereotypical aspects of experience and therefore perform a stabilising function in communication. (pp. 67-68)

Wishing someone a 'merry Christmas' is thus not just a reference to their religious beliefs and the polite thing to do on 25 December, but also evokes a range of emotions and feelings related to family, happiness, gift giving, good food and wine, et cetera. Needless to say, the fixed nature of the expression implies that you would not wish someone a 'Christmas merry', as this is ungrammatical.

\section{Equivalence}

No matter how fluent a translator is in the two languages they are translating between, they should always have access to a bilingual dictionary for the two languages in question - if only to double check their use of an idiom or other types of fixed expression. According to Svensén (2009):

The purpose of the bilingual dictionary is to provide lexical items in one language (the source language) with counterparts (equivalents) in another language (the target language) that are as near as possible with regard to meaning and usage. (p. 253)

This is essentially referring to equivalence at word level, but this meaning extends to fixed expressions and idioms, which are also contained in bilingual dictionaries. Unfortunately, an exact equivalent (assuming an 'exact equivalent' is ever possible between two languages) does not always exist for a fixed expression or more specifically an idiom in the target language, or there is more than one possible equivalent, thus it is necessary to look briefly at how lexicography treats idioms and equivalence.

\section{Absolute equivalence}

Potgieter (2006:183) calls the equivalent meanings in bilingual dictionaries TEs and draws attention to different types of equivalence that can occur when translating idioms. The first of these is absolute equivalence, where the translation equivalent(s) provided can be used in all contexts and circumstances in the target language (Potgieter 2006:185). Svensén (2009:258) also says that 'Where there is complete agreement between two expressions in different languages as regards content and usage, we have a case of full equivalence'. With respect to idioms and other types of fixed expressions, this obviously represents the ideal situation, but Svensén (2009:258) concludes that 'Such correspondence is quite unusual'.

\section{Partial equivalence}

Potgieter (2006:186) also refers to partial equivalence and divergence because an idiom can have more than one translation equivalent but says that dictionary users are not often given any guidance about which equivalent to choose. 
She further contends that although there are instances where one or more TEs can represent absolute equivalence, more often than not the TEs only represent partial equivalence, or divergence between the lemma (or idiom) and the translation equivalent(s).

Svensén (2009:258) also describes partial equivalence as: 'Where there is some, but not complete, agreement between two expressions in different languages as regards content and usage'.

\section{Divergence}

According to Gouws and Prinsloo (2005: 156-157) 'divergence is characterised by a one to more than one relation between source and target language forms'. They then distinguish between two types of divergence: the first of these, lexical divergence, is 'where a monosemous lexical item, functioning as lemma sign, has more than one translation equivalent' and as an example give the Afrikaans word gulheid which has two TEs in English, namely 'generosity' and 'liberality'. The second type is semantic divergence which 'prevails where the lemma represents a polysemous lexical item', an example of which is the word 'chair', for which three meanings are given, namely a 'seat for one person usually with a back', or a 'professorship', or 'a chairperson'. Potgieter (2006:186) feels that one of the most important aspects of the treatment of idioms in bilingual dictionaries, which requires attention from lexicographers is divergence and that they differentiate between lexical divergence and semantic divergence.

For lexical divergence, Gouws (cited in Potgieter 2006:186) says that it is vital that the lexicographer provides context for the various TEs so that the user can identify the typical contexts in which to use them.

Potgieter (2006:187) says about semantic divergence that the problem is that the user is not given information about the semantic differences between the different TEs, nor is the user told which are idioms and which are not. She goes on to say that if a translator is not aware of these semantic differences, then they can easily choose the wrong equivalent in a particular context and suggests that the best way that a lexicographer can ensure equivalence is to include additional information to assist the user in determining the correct equivalent to use.

\section{Zero equivalence}

Finally, Potgieter (2006:187) talks about zero equivalence (ZE) and surrogate equivalence (SE). According to Gouws and Prinsloo (2005:158), 'zero equivalence prevails where the target language has no item to be co-ordinated as a translation equivalent with a lemma representing a source language item', that is, there is no translation equivalent for a particular idiom in the target language. In this instance Potgieter (2006:188) says that a surrogate equivalent is needed in the absence of an absolute or partial equivalent and this usually takes the form of a description of the idiom. She concludes that it is therefore important that the user be told whether or not the translation equivalent is an idiom.

While this article is not strictly concerned with lexicography, the usefulness of the above definitions of different types of equivalence will become clear during the data analysis in evaluating the translations between Huisgenoot and You magazines.

\section{Strategies for translating idioms and fixed expressions}

In order to look at the translation of idioms and fixed expressions between Afrikaans and English, the strategies proposed in Baker (2011:75-86) are used. The first task for any translator dealing with a text containing idioms and other types of fixed expressions is to be able to identify them. This is often helped by the fact that the idiom or other type of fixed expression does not make sense in its context if interpreted literally. According to Baker (2011:69) they 'violate truth conditions, such as It's raining cats and dogs', something which is obviously not possible, or 'they do not follow the grammatical rules of the language, for example trip the light fantastic'. Baker (2011:69-70) highlights two cases where idioms and other types of fixed expressions can be misinterpreted by a translator who is unfamiliar with it. The first of these is that 'they seem transparent because they offer a reasonable literal interpretation and their idiomatic meanings are not necessarily signalled in the surrounding text'. As an example, she uses the idiom drain the radiator, used by truck drivers and which could quite easily be seen to mean the draining of the truck's radiator. It in fact refers to the driver urinating.

The second is that 'An idiom in the source language may have a very close counterpart in the target language which looks similar on the surface but has a totally or partially different meaning' (Baker 2011:70). Here she compares the following two idioms:

(1) Has the cat had/got your tongue?

(2) Donner sa langue au chat

Idiom (1) 'is used in English to urge someone to answer a question or to contribute to a conversation, particularly when their failure to do so becomes annoying'. In French, idiom (2) literally means 'to give one's tongue to the cat', but idiomatically means 'to give up, for example, when asked a riddle'. Both idioms literally relate to one's tongue and a cat, but their idiomatic meanings are quite different. It is thus a test of the translator's skills to identify idioms and interpret them correctly.

Baker (2011:71-75) says that 'Once an idiom or fixed expression has been recognised and interpreted correctly, the next step is to decide how to translate it into the target language', and then identifies the following four 'main difficulties in translating idioms and fixed expressions': 
- An idiom or fixed expression may have no equivalent in the target language. The way a language chooses to express, or not express, various meanings cannot be predicted and only occasionally matches the way another language chooses to express the same meanings.

- An idiom or fixed expression may have a similar counterpart in the target language, but its context of use may be different; the two expressions may have different connotations for instance or they may not be pragmatically transferrable.

- An idiom may be used in the ST in both its literal and idiomatic senses at the same time [...]. Unless the target language idiom corresponds to the source language idiom both in form and in meaning, the play on idiom cannot be successfully reproduced in the TT.

- The very convention of using idioms in written discourse, the contexts in which they can be used, and their frequency of use may be different in the source and target languages.

Once these challenges have been considered, the translator can move on to deciding which of Baker's seven strategies for the translation of idioms and other types of fixed expressions, detailed below, to use.

\section{Strategies for the translation of idioms}

\section{Using an idiom of similar meaning and form}

According to Baker (2011):

This strategy involves using an idiom in the target language which conveys roughly the same meaning as that of the sourcelanguage idiom and, in addition, consists of equivalent lexical items. (p. 76)

This likely represents the best-case scenario, but as Baker (2011:76) goes on to say, 'This kind of match can only occasionally be achieved'.

(3) Give the devil his due

(4) Gee die duiwel wat hom toekom

An example of such a translation is idiom (3), which can be translated into Afrikaans as idiom (4), and which, as mentioned above, also represents a literal translation. According to the HAT (Odendal et al. 1985:182) the Afrikaans idiom means 'gee aan elkeen die eer wat hom toekom'. According to the Collins English Dictionary (Black et al. 2009:459), the English equivalent means 'to acknowledge the talent or the success of an opponent or unpleasant person'. Because both these definitions are essentially the same, this then adheres to Svensén's definition of full equivalence as 'there is complete agreement between [the] two expressions in [English and Afrikaans] as regards content and usage' (2009:258).

\section{Using an idiom of similar meaning but dissimilar form}

Baker (2011) says that:

It is often possible to find an idiom or fixed expression in the target language which has a meaning similar to that of the source idiom or expression, but consists of different lexical items. (p. 78)
(5) Ek meneer en jy meneer, wie sal die wa smeer

(6) If two ride on a horse, one must ride behind

(7) Masters two will not do

(8) I stout and thou stout, who shall bear the ashes?

According to the HAT (Odendal et al. 1985:691), idiom (5) means 'as almal baas wil wees, wie sal dan Klaas wees?' where Klaas wees is defined as "n mindere wees' (Odendal et al. 1985:558). This idiom has (6), (7) and (8) as TEs in English. According to The Free Dictionary website (2016), of these, idiom (6) means 'When two people do something together, one of them will be the leader and the other will have to be subordinate', which is exactly the same as the Afrikaans definition where Klaas is the 'subordinate'. Here then we have partial equivalence as per Svensén's definition, as 'there is some, but not complete, agreement between [the] two expressions in [English and Afrikaans] as regards content' (2009:258).

In such a case where more than one translation equivalent is available to the translator in the target language, it is up to the translator to pick the one which they feel best fits into the TT in order to convey the meaning of the idiom in the ST:

(9) His fate is sealed

(10) Sy lot is beslis

(11) Dis klaar met kees

A further example of this would be translating idiom (9), which has two partial equivalents in Afrikaans, namely idioms (10) and (11), where the former is a more formal register and the latter more informal. The choice of translation will then depend on what context the original English idiom was used in.

\section{Borrowing the source language idiom}

The third strategy which Baker (2011:79) proposes is to use the source language idiom exactly as is, that is, not to translate it, but to leave it in the original source language. She says that (2011):

Just as the use of loan words is a common strategy in dealing with culture-specific items [...], it is not unusual for idioms to be borrowed in their original form in some contexts. (p. 79)

While this strategy might seem counterintuitive, in the absence of a full or partial translation equivalent, the idiom or other type of fixed expression in its source language form may be largely familiar to target language readers and thus understandable as is. This may even be the case where a suitable equivalent does in fact exist. An example of this would be an expression like 'absolutely fabulous' which can be translated into Afrikaans as absoluut fantasties, but this phrase does not capture the essence of the word 'fabulous'. This is similar to trying to translate lekker, or any expression containing lekker into English, where, although a suitable equivalent may exist, the word lekker just means so much more. The example of lekker kwaad wees in the Pharos AfrikaansEngels English-Afrikaans Woordeboek (Du Plessis et al. 2010:317) provides an English equivalent of 'be jolly cross' which, 
although technically a suitable equivalent, a phrase like 'lekker cross' would be just as good, if not even better as lekker is widely used in South African English, in an informal context.

\section{Translation by paraphrase}

This fourth strategy is, according to Baker (2011:80) 'by far the most common way of translating idioms when a match cannot be found in the target language', or if 'it seems inappropriate to use idiomatic language in the TT because of differences in stylistic preferences of the source and target languages'. This strategy thus involves giving an explanation in the TT of the meaning of an idiom in the ST, in the absence of a suitable equivalent idiom in the target language, or depending on the context, if the use of an idiom is not appropriate in the TT. In fact, this method could be applied to any idiom whereby its literal meaning is simply translated. Thus, an idiom such as gestewel en gespoor would be translated into English as 'fully dressed' and not with an idiomatic equivalent like 'suited and booted'. The translator thus, once again has to choose which to use, based on the context of the translation.

\section{Translation by omission of a play on idiom}

Baker's fifth strategy 'involves rendering only the literal meaning of an idiom in a context that allows for a concrete reading of an otherwise playful use of language' (2011:84), but according to Van der Merwe (2001:69), because both English and Afrikaans are Germanic languages with mutual origins, it is sometimes possible that an idiom be translated directly from English to Afrikaans, while maintaining the same idiomatic meaning - a fact she attributes to some idioms originating from the same source.

Indeed, no instances of this strategy were found in the data.

\section{Translation by omission of entire idiom}

As the name suggests, this strategy involves leaving out the idiom completely in the TT. Baker (2011:85) says that 'an idiom may sometimes be omitted altogether in the target text', for reasons such as 'no close match in the target language, its meaning cannot be easily paraphrased, or for stylistic reasons'. As with the fifth strategy, Van der Merwe (2001:69) is also relevant here.

\section{Compensation}

This final strategy (Baker 2011):

\begin{abstract}
Means that one may either omit or play down a feature such as idiomaticity at the point where it occurs in the source text and introduce it elsewhere in the target text. This strategy is not restricted to idiomaticity or fixed expressions and may be used to make up for any loss of meaning, emotional force or stylistic effect which may not be possible to reproduce directly at a given point in the target text. (p. 86)
\end{abstract}

As an example, Baker (2011) cites Mason (1982:29) regarding the puns in the French comic book series Asterrix, saying that:
Because they were unable to translate specific puns at the points at which they occurred in the text, translators of Astérix 'have sometimes resorted to inserting English puns (of equivalent impact rather than equivalent meaning) in different frames of the cartoon'. (p. 86)

\section{Methodology and analysis of results}

A total of 70 idioms and other types of fixed expressions were analysed for this study and the strategies used to translate them are summarised in Table 1.

All the idioms and other types of fixed expressions were placed in a spreadsheet and then it was determined which strategy was used to translate them, as well as their equivalence assessed. The results of this are discussed below.

\section{Translation using an idiom of similar meaning and form, and translation using an idiom of similar meaning but dissimilar form}

These first two strategies occurred extensively in the data set, at $31 \%$ and $27 \%$, respectively, representing more than half the translations $(58 \%)$. This is particularly striking in the first case, which at $31 \%$ is the most used strategy, as it represents the ideal case where full equivalence occurs. Baker (2011:76) says that 'This kind of match can only occasionally be achieved'.

(12) Die kind/baba met die badwater uitgooi

(13) Throw the baby out/away with the bath water

An example of this is idiom (12), which has (13) as an English translation equivalent according to the Pharos AfrikaansEngels English-Afrikaans Woordeboek (Du Plessis et al. 2010:792). Idiom (12) is defined in the HAT (Odendal et al. 1985:553) as 'die goeie tegelyk met die slegte verwerp' and idiom (13) is defined in the Collins English Dictionary (Black et al. 2009:118) as 'to lose the essential element by indiscriminate rejection', thus achieving full equivalence as per Svensén (2009:258), or absolute equivalence as per Potgieter (2006:185). What is however quite clear here is that the idiom was not used in its standard (frozen form) because in Afrikaans it was moenie die baba met die badwater uitgooi nie, thus using 'negative words', as suggested by Combrink (cited in Potgieter 2006:190) and in English it was 'avoid throwing the baby out with the bath water'. In fact, most of the idioms and other types of fixed expressions found in this study were not in their traditional (frozen) form, but this will be discussed again later.

TABLE 1: Summary of results.

\begin{tabular}{lcc}
\hline Strategy used to translate & \multicolumn{2}{c}{ Number of occurrences } \\
\cline { 2 - 3 } & $\boldsymbol{n}$ & $\mathbf{\%}$ \\
\hline Using an idiom of similar meaning and form & 22 & 31 \\
Using an idiom of similar meaning but dissimilar form & 19 & 27 \\
Borrowing the source language idiom & 0 & - \\
Translation by paraphrase & 21 & 30 \\
Translation by omission of a play on idiom & 0 & - \\
Translation by omission of entire idiom & 3 & 4 \\
Compensation & 0 & - \\
Questionable translations & 5 & 7 \\
\hline
\end{tabular}


(14) Vergewe en vergeet

(15) Forgive and forget

A second example, using fixed expression (14) has the English translation equivalent (15) according to the Pharos AfrikaansEngels English-Afrikaans Woordeboek (Du Plessis et al. 2010:998) and both are used as is in the magazines. Once again this represents full or absolute equivalence.
(16) In die kollig
(17) In the limelight
(18) Highlighted

Idiom (16) occurs twice in the data set and in the first instance is translated using an idiom of similar meaning and form, namely (17), which represents full equivalence. The second time however it is translated to (18) and in this instance it represents translation by paraphrase and as such represents partial equivalence as per Svensén (2009:258), because of the dissimilar form. Another example of this strategy would be the replacement of ' $n$ twisappel with the English 'a bone of contention'. Once again the form of the two idioms is different, but their meanings are essentially the same and can be used in the same contexts.

(19) Snuffel op die internet rond

(20) Surf the web

The example of idiom (19), translated to (20) is another example of translation using an idiom of similar meaning but dissimilar form. According to the Pharos Afrikaans-Engels English-Afrikaans Woordeboek (Du Plessis et al. 2010:1411), the correct form of the Afrikaans expression is 'op die net/ internet rondkuier/rondsnuffel/rondrits'. Here then the Afrikaans idiom, which admittedly has various forms has been altered in the magazine, while the English equivalent 'surf the net/internet' (Du Plessis et al. 2010:1411) is used in its standard form. This may be because of the frequent use of the English expression in Afrikaans, meaning that the correct form of the Afrikaans expression is not as familiar to Afrikaans speakers. Translation borrowing the source language idiom could thus have been used here, but the Afrikaans equivalent nevertheless achieves partial equivalence.

\section{Translation by paraphrase}

According to Baker (2011:80) 'This is by far the most common way of translating idioms [and other types of fixed expressions] when a match cannot be found in the target language', although in this study it did come a close second at $30 \%$ (21 out of the 70 ) to the first strategy's 31\%. Interestingly however, there were numerous examples where a suitable equivalent idiom or other type of fixed expression could have been used, but was not.

(21) Koppe bymekaar sit

(22) Discussions with a partner

(23) Put our/their heads together
For example, (21) was paraphrased into English as (22), but the Pharos Afrikaans-Engels English-Afrikaans Woordeboek (Du Plessis et al. 2010:291) gives (23) as an equivalent in English which would have represented translation using an idiom of similar meaning and form, which, as already mentioned, represents the ideal situation of full equivalence.

(24) Mis voor die son verdwyn

(25) Dissipate

(26) (One's problems etc.) vanish

The example of idiom (24) was also translated by paraphrase to (25) and while this is the correct verb to describe how mist clears up, that is, it dissipates, the Pharos Afrikaans-Engels English-Afrikaans Woordeboek (Du Plessis et al. 2010:635) suggests (26) as an equivalent.

Table 2 gives further examples of translation by paraphrase where an equivalent (in the third column) for the Afrikaans (first column) idiom or other type of fixed expression in Huisgenoot can be found for the translation (in the second column) in You, using the Pharos Afrikaans-Engels EnglishAfrikaans Woordeboek (Du Plessis et al. 2010).

(27) Op die vingers moet tik

(28) Iemand (goed/hard) oor/op die vingers tik

(29) Give someone a rap on/over the knuckles

In the case of idiom (27), the correct form of which is (28) (Du Plessis et al. 2010:660), a full equivalent, (29) (Du Plessis et al. 2010:1105) can be found and as both expressions are informal, the English equivalent could easily have been used.

\section{Translation by omission of entire idiom}

No examples of translation by omission of a play on idiom, or compensation were found, but three examples of translation by omission of an idiom were found, where an equivalent for each of these exists. They are as follows, with the idiom or other type of fixed expression as it appeared in Huisgenoot in the first column and the suggested equivalent in the second column of Table 3.

The first example is a direct translation, but 'be your own best friend' is an expression used in English and is thus equivalent

TABLE 2: Instances of translation by paraphrase.

\begin{tabular}{|c|c|c|}
\hline Huisgenoot & You & Alternative \\
\hline Beheervraat & Controlling & Control freak \\
\hline $\begin{array}{l}\text { Op die vingers } \\
\text { moet tik }\end{array}$ & Need reprimanding & $\begin{array}{l}\text { Give someone a rap on/over the } \\
\text { knuckles (Du Plessis et al. 2010:1105) }\end{array}$ \\
\hline Gaan dit dol & The pace is hectic & $\begin{array}{l}\text { It is a (real/bit of a) madhouse here } \\
\text { (Du Plessis et al. 2010:115) }\end{array}$ \\
\hline Huishen & $\begin{array}{l}\text { Spending time at } \\
\text { home }\end{array}$ & $\begin{array}{l}\text { Home bird, homebody, stay-at-home } \\
\text { (Du Plessis et al. 2010:232) }\end{array}$ \\
\hline Huishen & $\begin{array}{l}\text { You love to relax at } \\
\text { home }\end{array}$ & $\begin{array}{l}\text { Home bird, homebody, stay-at-home } \\
\text { (Du Plessis et al. 2010:232) }\end{array}$ \\
\hline Jou eie kop volg & Strong-willed & $\begin{array}{l}\text { Follow one' (own) mind; take the bit } \\
\text { between one's teeth (Du Plessis et al. } \\
\text { 2010:292) }\end{array}$ \\
\hline $\begin{array}{l}\text { Om op tone } \\
\text { te trap }\end{array}$ & $\begin{array}{l}\text { Try to avoid } \\
\text { provocation }\end{array}$ & $\begin{array}{l}\text { step/tread on someone's corns/toes } \\
\text { (Du Plessis et al. 2010:593) }\end{array}$ \\
\hline Job se geduld & Your patient nature & $\begin{array}{l}\text { Have the patience of Job (Du Plessis } \\
\text { et al. 2010:1223) }\end{array}$ \\
\hline
\end{tabular}


to the Afrikaans expression in both meaning and form. For the second example, the use of the idiom 'take the bull by the horns' in the English text would represent translation using an idiom of similar meaning and form, and thus full equivalence. The same is true of the expression 'in the good old days' as it is also used in everyday English and would also have represented translation using an idiom of similar meaning and form - a far better strategy than omission.

\section{Questionable translations}

As debate about whether translation is an art or a science is ongoing, Bell (1991) alludes to this ongoing debate when he says that:

The linguist inevitably approaches translation from a 'scientific' point of view, seeking to create some kind of 'objective' description of the phenomenon [...] It could, however, be argued that translation is an 'art' or a 'craft' and therefore not amenable to objective, 'scientific' description and explanation. (p. 4)

Thus there can often be cases where translators do not agree upon a particular translation and whether or not it is equivalent, or even correct. Five such examples were found in the data set and they are presented in the table below with the original Afrikaans expression from Huisgenoot in the first column, the questionable translation from You in the second column and suggested alternative equivalents in the third column of Table 4.

(30) Om in die wolke te wees

(31) Having your head in the clouds

Idiom (30) was probably translated to idiom (31) because of the apparent similarity of the two idioms, but the English idiom actually means to 'be in a dream world, that is, out of touch with reality', while the Afrikaans idiom relates to being happy or excited about something. A more appropriate English idiom, in addition to 'be delighted, tread/walk on air, be up in the air' (Du Plessis et al. 2010:711), could be to describe someone as being 'on cloud nine'. This then would use the strategy of translation using an idiom of similar meaning but dissimilar form, although both do allude to clouds.

(32) Swartgallige uitkyk

(33) A serious frame of mind

TABLE 3: Instances of translation by omission of entire idiom.

\begin{tabular}{ll}
\hline Huisgenoot & Suggested equivalent \\
\hline Probeer jou eie beste vriend wees & Try to be your own best friend \\
Die bul by die horings pak & Take the bull by the horns (Du Plessis et al. 2010:827) \\
[In] die goeie ou dae & In the good old days (Du Plessis et al. 2010:97) \\
\hline
\end{tabular}

The translation of fixed expression (32), to (33) in English, is not correct because the HAT (Odendal et al. 1985:1118) defines swartgallig as 'swaarmoedig; pessimisties' while the English equivalent 'a serious frame of mind' does not have the same negative connotations and merely refers to a serious approach to life, which is not necessarily a negative thing. A more accurate translation of swartgallige uitkyk would thus be to 'have a negative, or pessimistic approach, or outlook in life', which would be a direct translation.

(34) Aan jouself begin twyfel

(35) Do not begin to doubt yourself/your abilities

(36) Keep your eye on the prize

Expression (34) describes self-doubt based on one's abilities and is thus more accurately translated by (35). Expression (36) is more likely to be a strategy in overcoming such self-doubt and to motivate you to keep striving towards your goal.

(37) Al is jy nie op jou mond geval nie;

(38) The gift of the gab;

(39) Wel ter tale wees

To translate idiom (37), to (38), is once again misinterpreting the English idiom, probably because they both relate to the mouth and speaking. While the Afrikaans idiom relates to 'not/never be at a loss for words, have a fluent/ready/ smooth tongue (or a tongue in one's head), be lippy' (Du Plessis et al. 2010:357), idiom (38) relates to the ability to convince people to do, or buy something and would usually be attributed to a good salesperson who might also be described as being able to 'sell ice to Eskimos'. A better Afrikaans equivalent is given by Du Plessis et al. (2010:1017) as (39), although this is a very formal register, so it may not be suitable in all contexts.

(40) Gaan stap vir stap te werk

(41) Think things through carefully

(42) Do it step by step

Finally, expression (40) is not accurately translated by (41), as this would better describe the actions before a decision is made, but rather with an expression like (42), as this also recommends a methodical and planned way of actually doing a task. Using (42) instead of (41) would then represent a direct translation.

\section{Conclusion}

The results showed that the three most popular strategies were:

- translation using an idiom of similar meaning and form,

- translation using an idiom of similar meaning but dissimilar form, and

TABLE 4: Questionable translations.

\begin{tabular}{|c|c|c|}
\hline Huisgenoot & You & Suggested alternative translations \\
\hline Om in die wolke te wees & Having your head in the clouds & Be delighted, tread/walk on air, be up in the air (Du Plessis et al. 2010:711) \\
\hline Swartgallige uitkyk & A serious frame of mind & Pessimistic (Du Plessis et al. 2010:569) \\
\hline Aan jouself begin twyfel & Keep your eye on the prize & Do not begin to doubt yourself/your abilities \\
\hline Nie op jou mond geval wees nie & The gift of the gab & $\begin{array}{l}\text { Not/never be at a loss for words, have a fluent/ready/smooth tongue (or a tongue in one's head), be } \\
\text { lippy (Du Plessis et al. 2010:357) }\end{array}$ \\
\hline Gaan stap vir stap te werk & Think things through carefully & Do it step by step \\
\hline
\end{tabular}


- translation by paraphrase and that the following three strategies were not used at all:

- translation by borrowing the source language idiom,

- translation by omission of a play on idiom, and

- translation by compensation.

As mentioned above, despite Van der Merwe (2001:69), the sixth strategy of translation by omission was used, but there were no grounds for these omissions as suitable TEs were readily available for these examples and achieved full, or partial equivalence using one of the other strategies, specifically translation using an idiom of similar meaning and form, translation using an idiom of similar meaning but dissimilar form, or translation by paraphrase.

There were five instances where the translations were questionable and where different translators might disagree as to whether or not equivalence was achieved, but using Baker's strategies, and consulting a bilingual dictionary quite easily produced a translation equivalent that was in fact partially, or even fully equivalent.

The study also highlighted how much the form of the idioms and other types of fixed expressions are often changed. Despite the rules governing the use of these expressions discussed above (Baker 2011:67), almost all the examples were slightly, or even drastically altered from their 'frozen state'. Investigation of this was beyond the scope of this study, but no doubt requires future research.

While this study focused exclusively on assessing Baker's strategies for translating idioms and other types of fixed expression, there are other theories and approaches which can also be considered when translating idioms, but were outside of the scope of this study. As Baker's strategies were able to account for $93 \%$ of the translations in the study, including finding suitable equivalents when idioms had been omitted and where the translations were questionable, or even incorrect, on balance her strategies work well when translating idioms and other types of fixed expressions between Afrikaans and South African English.

\section{Acknowledgements}

The author declares that he has no financial or personal relationships which may have inappropriately influenced him in writing this article

\section{Competing interests}

The author declares that he has no financial or personal relationships that may have inappropriately influenced him in writing this article.

\section{References}

Baker, M., 2011, In other words, Routledge, Abingdon.

Baker, M. \& Saldanha, G., 2009, Routledge encyclopaedia of translation studies, Routledge, Abingdon.

Bell, R., 1991, Translation and translating, Longman, London.

Black, D., Brookes, I., Groves, R., Holmes, A., Hucker, H., McKeown, C., et al., 2009, Collins English dictionary, Harper Collins Publishers, Glasgow.

Brown, K. \& Miller, J., 2013, The Cambridge dictionary of linguistics, Cambridge University Press, Cambridge. https://doi.org/10.1017/CBO9781139049412

Charteris-Black, J., 2003, 'A prototype based approach to the translation of Malay and English idioms', in S. Granger, J. Lerot \& S. Petch-Tyson (eds.), Corpus-based approaches to contrastive linguistics and translation studies, pp. 123-140, Rodopi, Amsterdam.

Du Plessis, M., Pheiffer, F., Smith-Müller, W. \& Luther, J., 2010, Pharos Afrikaans-Engels English-Afrikaans Woordeboek, Pharos Woordeboeke, Cape Town.

Gouws, R.H. \& Prinsloo, D.J., 2005, Principles and practice of South African lexicography, Sun Press, Stellenbosch.

Martin, G., 2016, The meaning and origin of the expression: A bird in the hand is worth two in the bush, viewed 22 July 2016, from http://www.phrases.org.uk/meanings/ a-bird-in-the-hand.html

Media24, 2013a, Huisgenoot, No. 840. 18 Julie

Media24, 2013b, You, No. 345. 18 July

Media24, 2013c, Huisgenoot, No. 841. 25 Julie

Media24, 2013d, You, No. 346. 25 July

Media24, 2013e, Huisgenoot, No. 842. 01 Augustus

Media24, 2013f, You, No. 347. 01 August

Media24, 2013g, Huisgenoot, No. 843. 08 Augustus

Media24, 2013h, You, No. 348. 08 August

Media24, 2013i, Huisgenoot, No. 844. 15 Augustus

Media24, 2013j, You, No. 349. 15 August

Media24, 2013k, Huisgenoot, No. 845. 22 Augustus

Media24, 2013k, You, No. 350. 22 August

Media24, 2013m, Huisgenoot, No. 846. 29 Augustus

Media24, 2013n, You, No. 351. 29 August

Media24, 2013o, Huisgenoot, No. 847. 05 September

Media24, 2013p, You, No. 352. 05 September

Media24, 2013q, Huisgenoot, No. 848. 12 September

Media24, 2013r, You, No. 353. 12 September

Media24, 2013s, Huisgenoot, No. 849. 19 September

Media24, 2013t, You, No. 354. 19 September

Media24, 2016a, Huisgenoot, viewed 22 July 2016, from http://www.media24.com/ magazines/huisgenoot/

Media24, 2016b, You, viewed 22 July 2016, from http://www.media24.com/ magazines/you/

Moon, R., 1998, Fixed expressions and idioms in English, Oxford University Press, Oxford.

Odendal, F. \& Schoonees, P., 1985 (1965), Verklarende handwoordeboek van die Afrikaanse Taal, Perskor, Johannesburg.

Oxford University Press, 2016, Idiom, viewed 22 July 2016, from http://www. oxforddictionaries.com/definition/english/idiom?q=idiom

Potgieter, L., 2006, 'Die bewerking van idiome in tweetalige woordeboeke', Lexikos 16, 180-192.

Svensén, B., 2009, A handbook of lexicography, Cambridge University Press, Cambridge.

The Free Dictionary, 2016, If two ride a horse, one must ride behind, viewed 29 July 2016, from http://idioms.thefreedictionary.com/If+two+ride+on+a+horse,+one+ must+ride+behind

Van der Merwe, T., 2001, 'Enkele gedagtes oor die vertaling van idiomatiese verbindings', Southern African Linguistics and Applied Language Studies 19(1-2), 67-82. https://doi.org/10.2989/16073610109486276 